\title{
DESTAQUES
}

\section{HOMENAGENS AO CATEDRÉTICO APOSENTADO OSCAR MARTINS GOMES}

\section{TÍTULO DE PROFESSOR EMÉRITO}

A seção da imprensa da Reitoria assim registrou, em nota informativa aos jornais da Capital, no dia seguinte, a solenidade realizada a 29 de março de 1976, à tarde:

"O gabinete do reitor Theodócio Jorge Atherino foi pequeno para abrigar as pessoas que compareceram à entrega do título de "Professor Emérito", a Oscar Martins Gomes, na tarde de ontem. Autoridades, diretores de setores universitários, assessores do dirigente da UFP, amigos e familiares do homenageado, prestigiaram a solenidade, que durou cerca de uma hora. O Professor Atherino declarou aberta a sessão de outorga da honraria, "na data magna de Curitiba". Feliz coincidência, falou, "a cidade e seu cantor recebem a homenagem da UFP. O professor Oscar Martins Gomes, pelos seus méritos, e Curitiba, por tudo que representa e significa em nossa vida". E prosseguiu afirmando que "extremamente fácil é dar as razões do mérito do ilustre homenageado. Creio mesmo que citar estas razões é uma redundância, que não louve os seus méritos. $O$ que devemos é nos penitenciar por uma demora verdadeiramente injustificada, pois acredito que a Universidade deveria ser a primeira a fazer justiça a um de seus grandes professores".

Oscar Martins Gomes recebeu o diploma das mãos do diretor do Setor de Ciências Sociais Aplicadas, professor José Munhoz de Melo. Em seguida, o desembargador e catedrático Ary Florêncio Guimarães saudou o novo emérito da UFP, referindo-se a ele, como "amigo e companheiro de todas as horas, figura humana, tranquila e venerada, de personalidade polivalente". Martins Gomes falou emocionado, traçando uma auto-biografia, que denominou de "rememoração". Citou fatos importantes de sua vida e concluiu, dizendo ser o ato uma "passagem culminante de minha vida".

As palavras finais da solenidade foram as do reitor Theodócio 
Atherino, que acha o professor Oscar Martins Gomes "um símbolo". "Símbolo da dignidade, da modéstia e da grandeza do homem paranaense. Símbolo da unidade do mestre e do profissional, pelos trabalhos que realizou e que o elevaram no conceito entre seus concidadãos. Símbolo pela sensibilidade de escritor e de poeta em páginas que mostram a convivência harmônica, no mesmo homem, dos princípios da ética e da beleza da estética. Símbolo de uma sociedade que sabe cultuar a inteligência, a serenidade de espírito e a nobreza de caráter. E a Universidade se engrandece ao reconhecer a grandeza de um de seus mais ilustres mestres, o Professor Oscar Martins Gomes". 